\title{
Influence of Drying Methods on Antioxidant Activities and Immunomodulatory of Aqueous Extract From Soybean Curd Residue Fermentated by Grifola frondosa
}

\author{
Dan Zhu ${ }^{1}$, Hongyi Sun ${ }^{1}$, Shuhong $\mathrm{Li}^{1}$, Xuansheng $\mathrm{Hu}^{1}$, Xi Yuan ${ }^{1}$, Chao Han ${ }^{1} \&$ Zhenya Zhang ${ }^{1}$ \\ ${ }^{1}$ Graduate School of Life and Environmental Sciences, University of Tsukuba, Ibaraki, Japan \\ Correspondence: Zhenya Zhang, Graduate School of Life and Environmental Sciences, University of Tsukuba, \\ Ibaraki 305-8577, Japan. Tel: 81-29-853-4712. E-mail: zhang.zhenya.fu@u.tsukuba.ac.jp
}

Received: November 19, 2014 Accepted: December 1, 2014 Online Published: December 4, 2014

doi:10.5539/ijb.v7n1p82

URL: http://dx.doi.org/10.5539/ijb.v7n1p82

\begin{abstract}
The antioxidant activities and immunomodulatory of three aqueous extract from SCR fermented by G. frondosa (AE-ND, AE-OD and AE-FD) which were dried by different methods were evaluated. In this study, AE-OD exhibited higher antioxidant activities including DPPH radical scavenging activity $\left(\mathrm{IC}_{50} 13.03 \pm 0.47 \mathrm{mg} / \mathrm{mL}\right)$, $\mathrm{ABTS}^{+}$radical scavenging activity $\left(\mathrm{IC}_{50} 2.15 \pm 0.07 \mathrm{mg} / \mathrm{mL}\right.$ ) and reducing power (absorbance $2.39 \pm 0.01,5$ $\mathrm{mg} / \mathrm{mL}$ ). Likewise, oven drying method was more efficient on the survival of macrophage cells and the highest cell viability was $126.09 \pm 2.56 \%$ at the concentration of $80 \mu \mathrm{g} / \mathrm{mL}$. However, AE-FD could effectively and chronically enhance the apoptosis of HeLa cells $(52.27 \pm 0.59 \%)$ even incubated after $48 \mathrm{~h}$. The results indicated that aqueous extracts from SCR fermented by G. frondosa using different drying methods differently exhibited strong antioxidant and immunomodulatory activities. These could provide a theoretical basis for industrial production preservation of high-quality compounds in extracts from SCR.
\end{abstract}

Keywords: Soybean curd residue, Grifola frondosa, antioxidant activity, immunomodulatory

\section{Introduction}

Grifola frondosa (G. frondosa), a basidiomycete fungus belonging to the Polyporaceae family (Xu et al., 2010), is one kind of edible and officinal mushroom, whose fruiting body is called "Huishu hua" in Chinese and "Maitake" in Japanese. (Yang et al., 2014). "Shen nong ben cao jing" means that it has been frequently used for improving the ailment of the spleen and stomach, calming the nerve and the mind, and treating the hemorrhoids (Hsieh et al., 2006). Currently, mushrooms have become attractive on account of not only their unique and palatable edibleness as food or food-flavouring materials but also abundant and tremendous pharmacology as a source of physiologically beneficial medicine (Mau et al., 2004). Wide varieties of bioactive substances have been isolated from fruit bodies and liquid-cultured mycelium of G. frondosa (Fan et al., 2011; Chen et al., 2012) and exhibited remarkable biological activities such as anti-tumor (Cui et al., 2013), anti-HIV (Nanba et al., 2000), anti-hypertension (Bae et al., 2011), anti-viral (Gu et al., 2006), anti-diabetic (Kurushima, Kodama, Schar \& Turner, 2000), immunomodulatory (Lee et al., 2003).

Soybean curd residue (SCR) is a by-product of bean production manufacturing and 0.8 million tons of SCR is disposed in Japan annually (Li et al., 2014). On account for characteristics of high moisture content and short shelf life which make definite restriction on the recycle of the residue, SCR is just discharged as agro-industrial waste or incinerated artificially, except a little used as feed stuff. Actually, SCR is comprising of a good source of nutrients, including protein, dietary fiber, minerals, along with monosaccharides and oligosaccharides (Van et al., 1989). Hence, submerged fermentation process, as a novel approach, has been generally carried out to cultivate strains to achieve active compounds.

Drying is a considerable procedure on dehydration of food stuffs (Doymaz, 2005), vegetable processing (Larrosa et al., 2015) and biomass treatment (Garau, Simal, Rossello, \& Femenia, 2007), which guaranteed to preserve the quality and quantity of final products without enzymatic deterioration inhibition and microbial growth caused by moisture content of raw materials, to reach reduction of weight and volume, minimizing packaging, transportation and storage costs (Heras et al., 2014). 
Disparate drying methods of various materials including mushrooms have been applied, such as sunlight (Kooli, Fadhel, Farhat, \& Belghith, 2007), oven drying (Ali, Cone, Hendriks, \& Struik, 2014), vacuum (Tang, Santamaria, Bachman, \& Park, 2013), microwave (Zielinska et al., 2013) and freeze drying effect of palmitoylated alginate microencapsulation on viability of Bifidobacterium longum during freeze-drying and each method has its own characteristics (Borchani et al., 2011) since operation physical, structural, chemical, nutritional circumstances could be changed which can affect the quality attributes like texture, color, flavor and nutritional value (Di Scala \& Crapiste, 2008). Nevertheless, investigations on drying methods for evaluation of $G$. frondosa have not been reported yet. Consequently, the purpose of this study is to assess influence of different drying methods (non-drying, oven drying and freeze drying) on the antioxidant activities as well as immunomodulatory activities of aqueous extracts from SRC fermented by G. frondosa, which could provide theoretical basis for industrial production preservation of high-quality compounds extracts from SCR.

\section{Materials and Methods}

\subsection{Materials and Reagents}

Ascorbic acid, potassium ferricyanide, trichloracetic acid, ammonium sulfae, ferrous chloride were purchased from Wako Pure Chemical Osaka, Japan. Inc. 2,2'-azinobis-(3-ethylbenzothiazoline-6-sulfonic acid) (ABTS), 2,2-diphenyl-1-picry-hydrazyl (DPPH), minimal essential medium eagle medium (DMEM), fetal bovine serum (FBS) and penicillin-streptomycin solution were purchased from Sigma Aldrich, Inc. (Saint Louis, MO, USA). MTT stock solution $(5 \mathrm{mg} / \mathrm{mL}$ in D-PBS filtrated by $0.2 \mathrm{um}$ filter) and dimethyl sulfoxide (DMSO) were supplied by National Institute of advanced industrial science and technology, AIST, Japan. All other chemicals and solvents were analytical grade and utilized without further purification.

\subsection{Microorganism and Fermentation}

Fresh SCR (75\% moisture content) was obtained from Inamoto Co., Ltd. (Tsukuba, Japan). The impurities were removed from the crushed powder $(1.00 \mathrm{~g})$ with $80 \%$ ethanol at room temperature for $24 \mathrm{~h}$. The strain of $G$. frondosa ACCC51616 used in this study was supported by the China Agricultural Culture Collection. The mycelium, maintained on potato dextrose agar (PDA) slants and was subcultured every three months, incubated at $25^{\circ} \mathrm{C}$ for 10 days on a modified agar plate which consisted of the following: glucose $2.0 \%$, potato extract $0.4 \%$, agar 2.0\%, mineral salt solution $\left(\mathrm{KH}_{2} \mathrm{PO}_{4} 0.3 \%\right.$, and $\left.\mathrm{MgSO}_{4} \cdot 7 \mathrm{H}_{2} \mathrm{O} 0.15 \%\right)$. The mycelia of G. frondosa was transferred into a sterile petridish (diameter: $100 \mathrm{~mm}$ ) containing $20 \mathrm{~mL}$ of PDA and incubated at $25^{\circ} \mathrm{C}$ for 6 days. Afterwards, $100 \mathrm{~mL}$ experimental liquid inoculum whose composition was the same as that of medium above except agar was not included, was conducted in a $300 \mathrm{~mL}$ flask containing $100 \mathrm{~mL}$ medium with ten units of activated mycelia agar, which was a $5 \mathrm{~mm} \times 5 \mathrm{~mm}$ square individually achieved by a sterilized self-designed cutter and then in order to activate the culture, it was incubated in a rotary shaker at $25^{\circ} \mathrm{C}, 120 \mathrm{rpm}$ for 7 days. Solid-state fermentation was administrated in a $200 \mathrm{~mL}$ flask with wet SCR as the substrate under optimal culture conditions by pipettes. All the media were autoclaved at $121^{\circ} \mathrm{C}$ for $15 \mathrm{~min}$ prior to utilization. The whole medium including mycelium was smashed using a sterilized blender and used as the inoculums in the following experiments.

\subsection{Cell Line}

The macrophage cell line (RAW 264.7) and human cervical cancer cell line (HeLa) were obtained from Japanese Riken bioresource center Cell Bank and maintained in DMEM containing 10\% (v/v) FBS and antibiotics (100 $\mathrm{U} / \mathrm{mL}$ penicillin and $100 \mu \mathrm{g} / \mathrm{mL}$ streptomycin) at $37^{\circ} \mathrm{C}$ in a humidified atmosphere of $5 \%(\mathrm{v} / \mathrm{v}) \mathrm{CO}_{2}$ in a water jacket incubator (ASTEC APC-30D CO $\mathrm{CO}_{2}$ incubator, Fukuoka, Japan). Cells were cultured for 2-3 days to reach the logarithmic phase and utilized for experiments.

\subsection{Aqueous Extracts from $G$. frondosa}

The treatment of aqueous extracts was according to a literature procedure with a few modifications (Yuan et al., 2013). Aqueous extracts were obtained with hot water (1:30 ratio of raw material to water, w/v) for $2 \mathrm{~h}$ and were separated from insoluble residue by centrifugation $\left(8000 \times \mathrm{g}\right.$ for $15 \mathrm{~min}$, at $\left.4{ }^{\circ} \mathrm{C}\right)$. The supernatant was filtered through a Whatman GF/B filter paper and concentrated in a rotary evaporator under reduced pressure at $50{ }^{\circ} \mathrm{C}$. Ultimately, materials were acquired after lyophilization and reserved at $-20^{\circ} \mathrm{C}$ for further experiments.

\subsection{Drying Procedures of Raw Materials}

In order to evaluate the influences of drying methods on the bio-activities of substrate, it was carried out three distinctive groups: Non-drying (ND), Oven drying (OD) and Freeze drying (FD). The sample (Non-drying aqueous extract) AE-ND was carried out directly crush without any drying approach. The sample (Oven drying aqueous extract) AE-OD was implemented at $50{ }^{\circ} \mathrm{C}$ in an electro-thermostatic blast oven (EYELA WFO-700, JAPAN), which selected to preserve the quality in previous study. It was reserved in a desiccator for 2 days to maintain 
equilibrium of individual moisture and the final humidity about $10 \%$ was determined. The sample (Freeze drying aqueous extract) AE-FD was processed in a vacuum freeze drier (EYELA FREEZE DRYER FDU-506, JAPAN) at $35^{\circ} \mathrm{C}$ heating shelf temperature, $553 \mathrm{~Pa}$ cavity pressure and $-45^{\circ} \mathrm{C}$ cold trap temperature for $48 \mathrm{~h}$.

\subsection{The Determinations of the Antioxidant Properties}

\subsubsection{DPPH Radical Scavenging Activity Assay}

DPPH scavenging activities of aqueous extracts was determined according to (Nakajima et al., 2007; Yang et al., 2006) by using 1,1-diphenyl-2-picryl-hydrazyl. Concisely, Aliquots $(0.5 \mathrm{~mL})$ of diverse concentrations of raw materials were mixed with $2 \mathrm{~mL}(25 \mu \mathrm{g} / \mathrm{mL})$ of a MeOH solution of DPPH and shaken vigorously. After $30 \mathrm{~min}$ of reaction in darkness, the optical density (O.D.) was determined at a wavelength of $517 \mathrm{~nm}$ with a spectrophotometer (SHIMADZU UV-1600, JAPAN). Decrease of the DPPH solution absorbance indicated an increase of the DPPH radical scavenging activity. Ascorbic acid was used as the positive control. The DPPH radical-scavenging activity was calculated by the following Equation (1):

$$
D P P H \text {-scavenging activity }(\%)=\left(1-A_{\text {sample }} / A_{\text {control }}\right) \times 100 \%
$$

Where $\mathrm{A}_{\text {control }}$ is the absorbance without samples and $\mathrm{A}_{\text {sample }}$ the absorbance in the presence of the samples.

$\mathrm{IC}_{50}$ value $(\mathrm{mg} / \mathrm{mL})$ was the effectual concentration at which DPPH radicals were scavenged by $50 \%$ and was obtained by interpolation from a linear regression analysis.

\subsubsection{Reducing Power Assay}

The reducing power of the fractions was determined according to the method of Shi et al., (2013) with slight modifications. An aliquot of each sample $(1.0 \mathrm{~mL})$, containing different concentrations $(0.3125-10.00 \mathrm{mg} / \mathrm{mL})$, was mixed with $1.0 \mathrm{~mL}$ of phosphate buffer $(0.2 \mathrm{M}, \mathrm{pH} 6.6)$ followed by $1.0 \mathrm{~mL}$ of $1 \%(\mathrm{w} / \mathrm{v})$ potassium ferricyanide $\left[\mathrm{K}_{3} \mathrm{Fe}(\mathrm{CN})_{6}\right]$. The mixture was cooled $5 \mathrm{~min}$ at $-20{ }^{\circ} \mathrm{C}$ after incubating for $20 \mathrm{~min}$ in a water bath at $50{ }^{\circ} \mathrm{C}$. Then $1.0 \mathrm{~mL}$ of $1 \%$ trichloroacetic acid (TCA) was added and precipitate was centrifuged at $4000 \times \mathrm{g}$ for 10 min. The supernatant $(1.0 \mathrm{~mL})$, mixed with $2.0 \mathrm{~mL}$ of distilled water and $0.4 \mathrm{~mL}$ of $0.1 \%$ ferric chloride $\left(\mathrm{FeCl}_{3}\right)$, was standing at ambient temperature for $15 \mathrm{~min}$. Eventually, the absorbance was measured at $700 \mathrm{~nm}$ against a blank in the spectrophotometer, with higher absorbance values indicative of greater reducing capacity of ferric $\left(\mathrm{Fe}^{3+}\right)$ to ferrous $\left(\mathrm{Fe}^{2+}\right)$ ions. Ascorbic acid was invoked as the positive control. There is a positive correlation between absorbance value and reducing powering.

\subsection{3 $\mathrm{ABTS}^{+}$Radical Scavenging Activity Assay}

The radical scavenging activities of the polysaccharides against radical cations $\left(\mathrm{ABTS}^{-+}\right)$were measured using the methods with some modifications (Shi et al., 2013). When combined with an oxidant ( $2.45 \mathrm{mM}$ potassium persulfate), ABTS ( $7 \mathrm{mM}$ in $20 \mathrm{mM}$ sodium acetate buffer) was maintained to create a stable, dark blue-green radical solution in the dark at room temperature for $12-16 \mathrm{~h}$ before use. The working $\mathrm{ABTS}^{+}$solution was supposed to be diluted with ethanol of the stock solution to achieve an absorbance value of $0.70( \pm 0.02)$ at $734 \mathrm{~nm}$ wavelength when samples $(0.15 \mathrm{~mL})$ of various concentration $(0.3125-10.00 \mathrm{mg} / \mathrm{mL})$ were vigorously mixed with $2.85 \mathrm{~mL}$ of $\mathrm{ABTS}^{+}$solution. Ascorbic acid was used as the positive control. Eventually, the absorbance was measured at $734 \mathrm{~nm}$ after incubation at room temperature for $10 \mathrm{~min}$. The scavenging activity of the ABTS free radicals was calculated using the following Equation (2):

$$
A B T S^{+} \text {radical scavenging activity }(\%)=\left(A_{0}-A_{1}\right) / A_{0} \times 100 \%
$$

where $\mathrm{A}_{0}$ is the absorbance of control without sample and $\mathrm{A}_{1}$ is the test sample without $\mathrm{ABTS}^{+}$.

$\mathrm{IC}_{50}$ value $(\mathrm{mg} / \mathrm{mL})$ was the effective concentration at which $\mathrm{ABTS}^{+}$radical scavenging activity was scavenged by $50 \%$ and was obtained by interpolation from a linear regression analysis.

\subsection{Cell Viability Assay}

The viability and proliferation of murine macrophage (RAW 264.7) cell line was accomplished by MTT reduction assay (Sun et al., 2013) with minor modifications to evaluate the immunomodulatory effects of SCR fermented by G. frondosa using three drying methods. Briefly, RAW 264.7 cells were cultured in DMEM medium at $37{ }^{\circ} \mathrm{C}$ in a $5 \% \mathrm{CO}_{2}$ atmosphere to logarithmic phase. Cells were harvested, and an aliquot $(100 \mu \mathrm{L})$ of suspension $\left(5 \times 10^{4}\right.$ cells $/ \mathrm{mL})$ were dispensed into a 96 -well plate $\left(2 \times 10^{3}\right.$ cells/well) and pre-incubated at $37{ }^{\circ} \mathrm{C}$ in a $5 \% \mathrm{CO}_{2}$ atmosphere for $24 \mathrm{~h}$. Then cells were exposed to various concentrations of extracts $(0,20,40,60,80,100 \mu \mathrm{g} / \mathrm{mL})$ for $48 \mathrm{~h}$. After drugs exposure, 96-well plate was removed from incubator and $10 \mu \mathrm{L}$ MTT stock solution $(0.5$ $\mathrm{mg} / \mathrm{mL}$ ) was added to each well incubated at $37^{\circ} \mathrm{C}, 5 \% \mathrm{CO}_{2}$ for $4 \mathrm{~h}$. Afterwards, 96 -well plate was removed from incubator and aspirated the solution and further added $100 \mu \mathrm{L}$ DMSO to each well and rotated the plate for $10 \mathrm{~min}$ 
to distribute evenly. Ultimately, absorbance was measured with an ELISA reader (BIO-RAD iMark ${ }^{\mathrm{TM}}$ Microplate Reader, JAPAN) at $490 \mathrm{~nm}$. Cell viability rate was calculated as the percentage of MTT absorbance. The inhibition rate was calculated using Equation (3).

$$
\text { Cell viability }(\%)=\left(A_{\text {sample }}-A_{\text {blank } 1}\right) /\left(A_{\text {control }}-A_{\text {blank } 2}\right) \times 100 \%
$$

where $A_{\text {sample }}$ is the absorbance of the sample; $A_{\text {blank } 1}$ is the absorbance of medium and sample; $A_{\text {control }}$ is the absorbance of control group and $\mathrm{A}_{\text {blank } 2}$ is the absorbance of medium.

\subsection{Anti-proliferation Effect of Aqueous Extracts on HeLa cells}

HeLa cells were operated to detect the anti-proliferation activity of aqueous extracts from SCR. Anti-proliferation effect of different aqueous extracts was determined by the MTT assay and specific experimental procedures were basically consistent except cells and does of drugs $(0,50,100,150,200,250 \mu \mathrm{g} / \mathrm{mL})$ changed. Inhibition rate was calculated as the percentage of MTT absorbance. The inhibition rate was calculated using Eq (4).

$$
\text { Inhibition rate }(\%)=\left[1-\left(A_{\text {sample }}-A_{\text {blank } 1}\right) /\left(A_{\text {control }}-A_{\text {blank } 2}\right)\right] \times 100 \%
$$

\subsection{Statistical Analysis}

All treatments in the present study were performed in triplicate. Data were expressed as means \pm standard deviations (S.D.) and analyzed by using a SPSS package (SPSS 19.0 for windows, SPSS Inc., Chicago, IL) one-way analysis of variance (ANOVA) test for mean differences among the samples. P-Values of $<0.05$ were considered to be statistically significant.

\section{Results and Discussion}

\subsection{DPPH Scavenging Radical Activity Assay}

Table 1. Antioxidant activities (DPPH, $\mathrm{ABTS}^{+}$, reducing power) of aqueous extracts using three drying methods from SCR fermented by G. frondosa

\begin{tabular}{cccc}
\hline Sample & \multicolumn{2}{c}{$\mathrm{IC}_{50}{ }^{\mathrm{d}}(\mathrm{mg} / \mathrm{mL})$} & Reducing power $^{\mathrm{e}}$ \\
\cline { 2 - 3 } & $\mathrm{DPPH}^{\mathrm{e}}$ & $\mathrm{ABTS}^{+\mathrm{e}}$ & \\
\hline AE-ND & $9.86 \pm 1.03^{\mathrm{a}}$ & $2.48 \pm 0.02^{\mathrm{a}}$ & $1.19 \pm 0.04^{\mathrm{a}}$ \\
AE-OD & $13.03 \pm 0.47^{\mathrm{a}}$ & $2.15 \pm 0.07^{\mathrm{b}}$ & $2.39 \pm 0.01^{\mathrm{b}}$ \\
AE-FD & $108.85 \pm 3.78^{\mathrm{b}}$ & $3.04 \pm 0.14^{\mathrm{c}}$ & $1.14 \pm 0.01^{\mathrm{a}}$ \\
\hline
\end{tabular}

${ }^{\mathrm{a}, \mathrm{b}, \mathrm{c}}$ Different superscript letters in the same column indicate significant difference $\left({ }^{*} p<0.05\right)$.

${ }^{\mathrm{d}} \mathrm{IC}_{50}$ value: the concentration at which the antioxidant activity was $50 \%$.

${ }^{\mathrm{e}}$ Values are expressed as means \pm S.D. (standard deviation) of three parallel measurements.

AE-ND: aqueous extract without drying; AE-OD: oven drying. AE-FD: freeze drying.

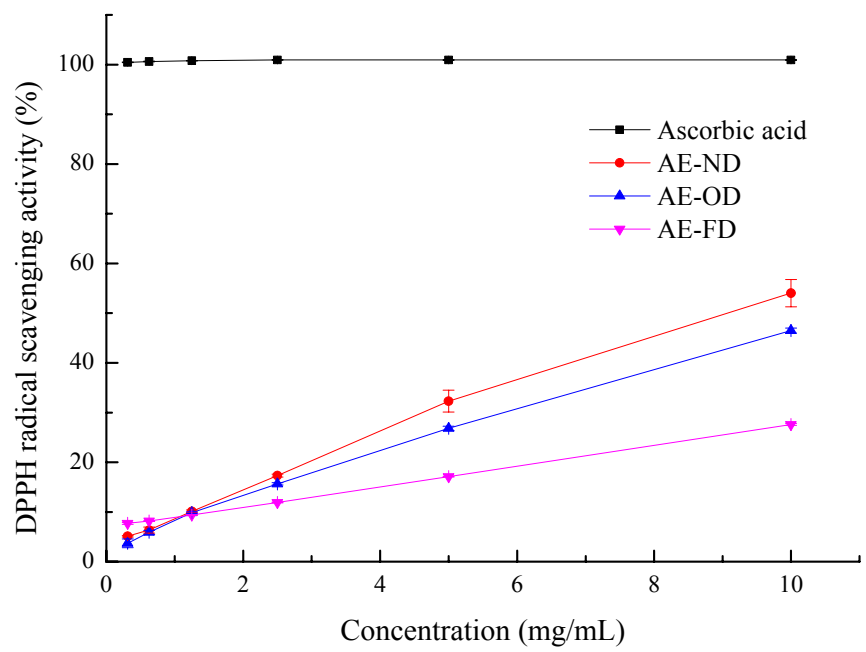

Figure 1. DPPH radical scavenging activities of aqueous extracts of SCR fermented by G. frondosa 
To investigate efficiently the capacity to scavenge specific free radicals is a prevailing strategy to identify the antioxidant activity of definite compounds in vitro (Sascha, Nicklisch \& Herbert, 2014). DPPH is a stable free radical used for determining the electron-donating capacity (Brand-Williams, Cuvelier \& Berset, 1995). The mechanism of DPPH radical scavenging activity is that DPPH radical carrying a single electron in an alcohol solution can be exhibited a strong absorption at $517 \mathrm{~nm}$ of UV spectrum. However, when a free radical scavenger makes the pairing single-electron to absorb gradually disappear, the number of electrons which fade into the extent of its acceptance of the quantitative relationship can be used for rapid quantitative analysis of the spectrophotometer. In other words, the degree of decolorization is associated with free radical scavenging capacity.

Figure 1 indicates the data of the DPPH radical scavenging activities of aqueous extracts of three drying methods from $G$. frondosa with various concentrations. According to Figure 1, the scavenging rates of aqueous extracts using three drying methods constantly increased from 0.3125 to $10 \mathrm{mg} / \mathrm{mL}$, which could be concluded that all samples were totally in a dose-dependent manner, consistent with the researches of bioactivity of $G$. frondosa . Nevertheless, compared with ascorbic acid, the positive group, the highest value obtained by AE-ND was $54.02 \pm$ $2.76 \%$ at the concentration of $10 \mathrm{mg} / \mathrm{mL}$, on account of various compounds mixed. Among three drying methods, AE-ND displayed more significant DPPH radical scavenging activity except under extremely low concentration which implied drying process for $G$. frondosa played a negative role by means of destroying interior construction and impairing scavenging capacity. $\mathrm{IC}_{50}$ values, half maximal (50\%) inhibitory concentration, were calculated likewise and outlined in Table 1. $\mathrm{IC}_{50}$ of AE-ND, AE-OD and AE-FD were $9.79 \mathrm{mg} / \mathrm{mL}, 13.05 \mathrm{mg} / \mathrm{mL}$ and 108.98 $\mathrm{mg} / \mathrm{mL}$, respectively. Therefore, it was demonstrated that the effects of drying methods including non-drying and oven drying were significant on DPPH radical scavenging activity.

\subsection{Reducing Power Assay}

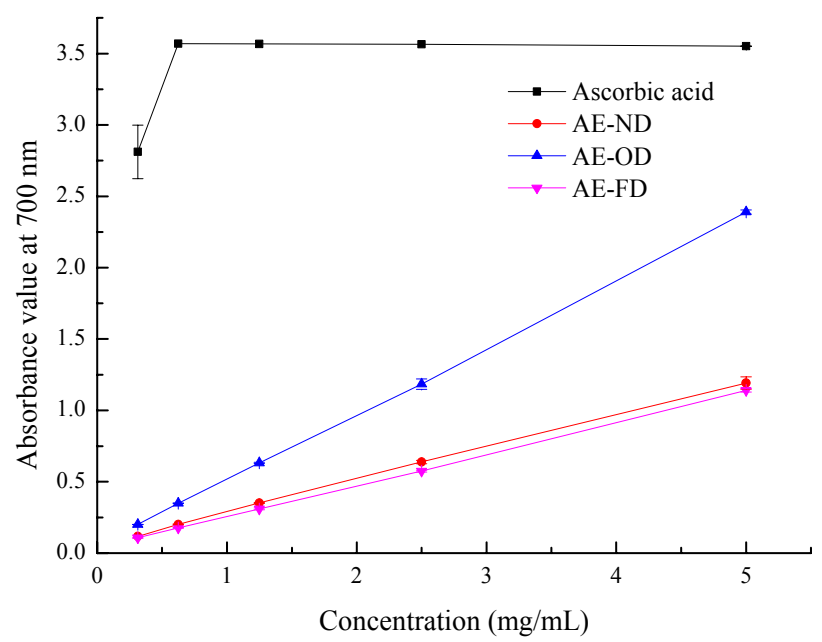

Figure 2. Reducing power of aqueous extracts of SCR fermented by G. frondosa

The reaction mechanism reducing power assay, in essence, is the process of measuring ferrous ion $\left(\mathrm{Fe}^{2+}\right)$ formation monitored spectrophotometrically at $700 \mathrm{~nm}$, based on the theory of transfer ability from ferric $\left(\mathrm{Fe}^{3+}\right)$ to ferrous $\left(\mathrm{Fe}^{2+}\right)$ ion through the donation of an electron (Lue et al., 2010). An assay like reducing power could support a basic theoretical foundation for efficient electrons contribution to a concrete antioxidant, performing on the termination of free radical chain reactions.

In summary, it could be clearly observed from Figure 2 that three drying methods had fantastic reducing power and all samples were totally in a dose-dependent manner as same as the effect of DPPH radical scavenging activity they possessed. At the concentration of $5 \mathrm{mg} / \mathrm{mL}$, absorbance values at $700 \mathrm{~nm}$ of AE-ND, AE-OD and AE-FD were $1.19 \pm 0.04,2.39 \pm 0.012$ and $1.14 \pm 0.014$, respectively, which indicated that aqueous extracts from SCR fermented by G. frondosa could be further isolated and purified for obtaining higher active and complicated ingredients. Besides, AE-OD exhibited the strongest reducing power at any given concentration as compared with other two samples, of which one line almost coincided with another. Depend on this result, various drying methods could indeed affect the antioxidant activities of raw materials, also consistent with previous research (Fan, $\mathrm{Li}$, Deng \& Ai, 2012; Li et al., 2014 \& Suvarnakuta, Chaweerungrat \& Devahastin, 2011). Hence, effects of drying methods including oven drying and freeze drying were noteworthy on hydroxyl radical scavenging activity. 


\subsection{ABTS $^{+}$Radical Scavenging Activity Assay}

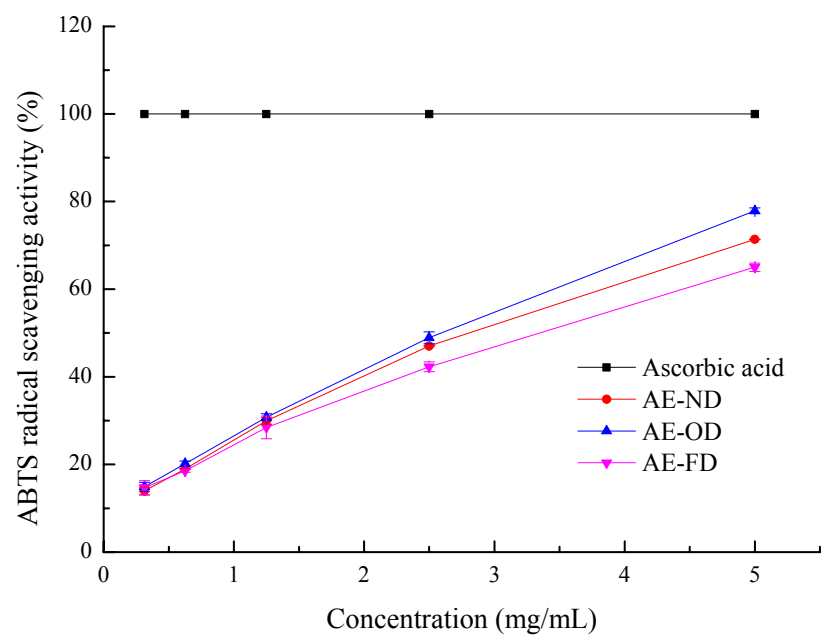

Figure 3. $\mathrm{ABTS}^{+}$radical scavenging activities of aqueous extracts of SCR fermented by G. frondosa

In specification, the ABTS assay based on the generation of a blue/green $\mathrm{ABTS}^{+}$that can be reduced by antioxidants (Floegel et al., 2011). In particular, ABTS is oxidized with appropriate oxidants, such as hydrogen peroxide, to form a blue-green water-soluble $\mathrm{ABTS}^{+}$. While antioxidants inhibited the generation and enhanced restoration of $\mathrm{ABTS}^{+}$, the color of the solution could lighten the absorbance value at $734 \mathrm{~nm}$ absorbance band and that meant the sample cleared $\mathrm{ABTS}^{+}$radicals possessed the antioxidant activity.

$\mathrm{ABTS}^{+}$radical scavenging activities of aqueous extracts of three drying methods from G. frondosa were summarized in Figure 3. Generally, all samples using different drying methods were ascended steadily and were completely in a dose-dependent manner. And there was a delicate difference among three samples above 1.25 $\mathrm{mg} / \mathrm{mL}$. Specifically, the order of three samples was as followed: AE-OD, AE-ND and AE-FD and at the concentration of $5 \mathrm{mg} / \mathrm{mL}$, the inhibition rates were $77.88 \pm 0.68 \%, 71.37 \pm 0.09 \%, 65.02 \pm 0.94 \%$, respectively. From Table 1, $\mathrm{IC}_{50}$ values of individual sample were $2.15 \mathrm{mg} / \mathrm{mL}, 2.48 \mathrm{mg} / \mathrm{mL}$ and $3.05 \mathrm{mg} / \mathrm{mL}$, which declared that oven drying method was more advantageous than the other two drying processes on $\mathrm{ABTS}^{+}$radical scavenging.

\subsection{Immunological Activities of Aqueous Extracts on RAW 264.7 Cells}

Inflammation is a protective response mechanism (Kim, Hwang \& Park, 2014) to the release of a large amount of inflammatory mediators, such as pro-inflammatory cytokines, NO, iNOS, and COX-2 (Kwon et al., 2013) due to bacteria and viruses invaded into the body (Choi, Kim \& Han, 2014) which causes chronic inflammatory diseases such as arthritis, asthma, multiple sclerosis, and atherosclerosis. (Lee, Ryu, Lee \& Lee, 2012). Murine macrophage (RAW 264.7) cell with strong adhesion and the ability to engulf the antigen, belonging to the immune system, played multiple roles in the study of phagocytosis, cell-mediated immunity and molecular immunology (Oh et al., 2012).

The immunological effects of aqueous extracts from SCR fermented by G. frondosa on cell viabilities of macrophage cells were shown in Figure 4. It could be demonstrated that three kinds of drying methods enhanced the proliferation of RAW 264.7 cells for $24 \mathrm{~h}$, especially at the concentration of $40 \mu \mathrm{g} / \mathrm{mL}$ treated with AE-ND, at the concentration of $80 \mu \mathrm{g} / \mathrm{mL}$ treated with AE-OD and AE-FD, which stated that various drying methods exhibited different degrees of proliferation of macrophage cells also meant a higher immunological effect achieved via drying methods at a constant concentration. Oven drying method was more efficient on the survival of macrophage cells on account of the highest cell viability (126.09 $\pm 2.56 \%)$ was obtained at the concentration of 80 $\mu \mathrm{g} / \mathrm{mL}$ when treated with AE-OD. Furthermore, after this the stimulation effect lowered with increase of dosage due to the toxicity of samples themselves. As for incubation of $48 \mathrm{~h}$, cells treated with samples were expressed varying levels of descent which proved long-term excessively exposed to SCR was not suitable for the culture of RAW 264.7 cells. 

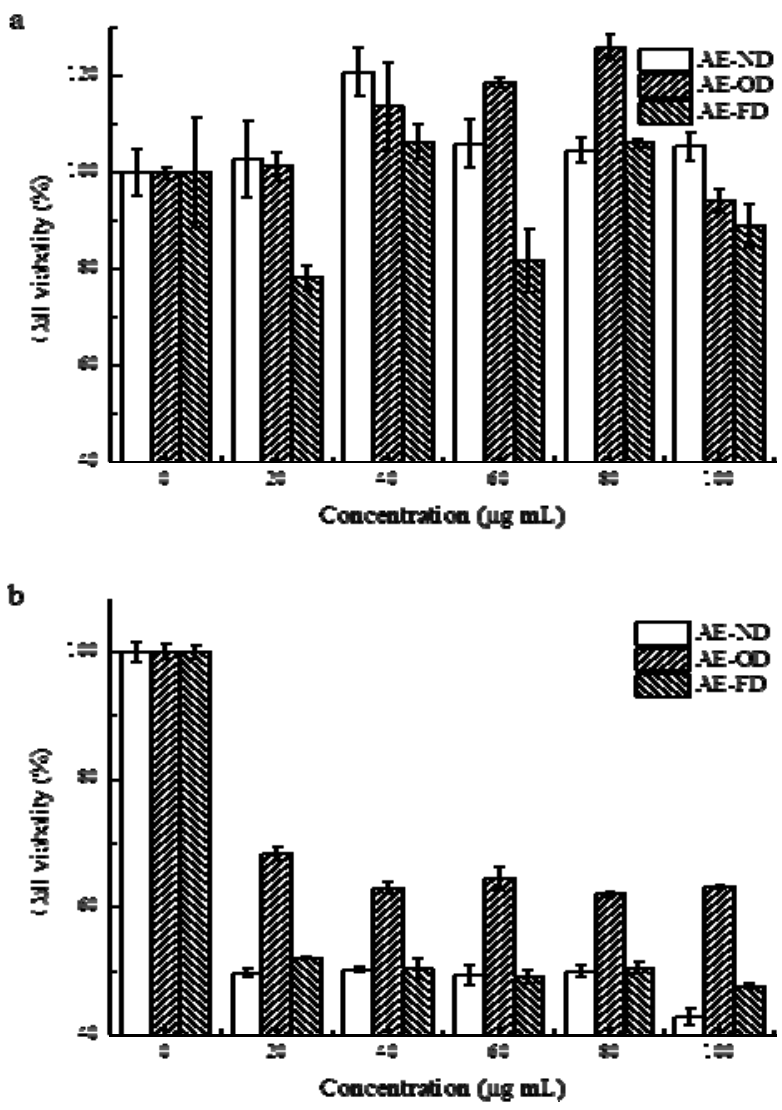

Figure 4. Immunological activities of aqueous extracts from SCR fermented by G. frondosa on RAW 264.7 cells. a: cells were incubated with various concentrations $(0,20,40,60,80,100 \mu \mathrm{g} / \mathrm{ml})$ of AE-ND, AE-OD and AE-FD for $24 \mathrm{~h}$. b: cells were incubated with various concentrations $(20,40,60,80,100 \mu \mathrm{g} / \mathrm{ml})$ of AE-ND, AE-OD and

AE-FD for 48 h. Data are expressed as means \pm S.D. $(n=3)(p<0.05$ in comparison with control)

\subsection{Anti-proliferation of Aqueous Extracts from SCR Fermented by G. frondosa on HeLa Cells}

Current therapies including surgery, chemotherapy and radiotherapy (Feng \& Chien, 2003) have been applied for the treatment of advanced stages of cancer, which is the malignant and bloodcurdling disease threatening the survival and development of humanity (Mohanty \& Sahoo, 2010). Nevertheless, scientists are searching for substituted compounds extracted from natural plants or biomass since above treatments are generally associated with serious side effects. (Kwon et al., 2007).

HeLa cell line, the transformation of human papilloma virus (Human Papillomavirus 18 or HPV18), has been a very important tool and widely used in cancer research, biological experiments or cell culture to evaluate and determine anti-inflammatory (Hilmi et al., 2003), cytotoxicity (Parthiban et al., 2011) and proliferation and apoptosis (Chen et al., 2014). Figure 5 showed the apoptosis of HeLa cells incubated with drugs at the concentrations of $0,50,100,150,200,250 \mu \mathrm{g} / \mathrm{ml}$ of for $24 \mathrm{~h}$ and $48 \mathrm{~h}$. At first $24 \mathrm{~h}$, three samples were expressed preeminent anti-proliferation activity in a dose-dependent manner. The inhibition rates of AE-ND, AE-OD and AE-FD were $73.41 \pm 3.22 \%, 45.79 \pm 0.50 \%$ and $67.53 \pm 0.93 \%$ at the concentration of $250 \mu \mathrm{g} / \mathrm{ml}$, respectively. Contrast to the results of antioxidant activities of previous study, the aqueous extract using freeze drying showed higher ability which might most of deterioration and microbiological reactions are stopped which gives a final product of excellent quality due to absence of liquid water and the low temperature required for the process (Ratti, 2001). After incubation for $48 \mathrm{~h}$, inhibition rates still kept at a high level which indicated it was meaningful to investigate the extracts from SCR because of enduring immunomodulatory effect. 


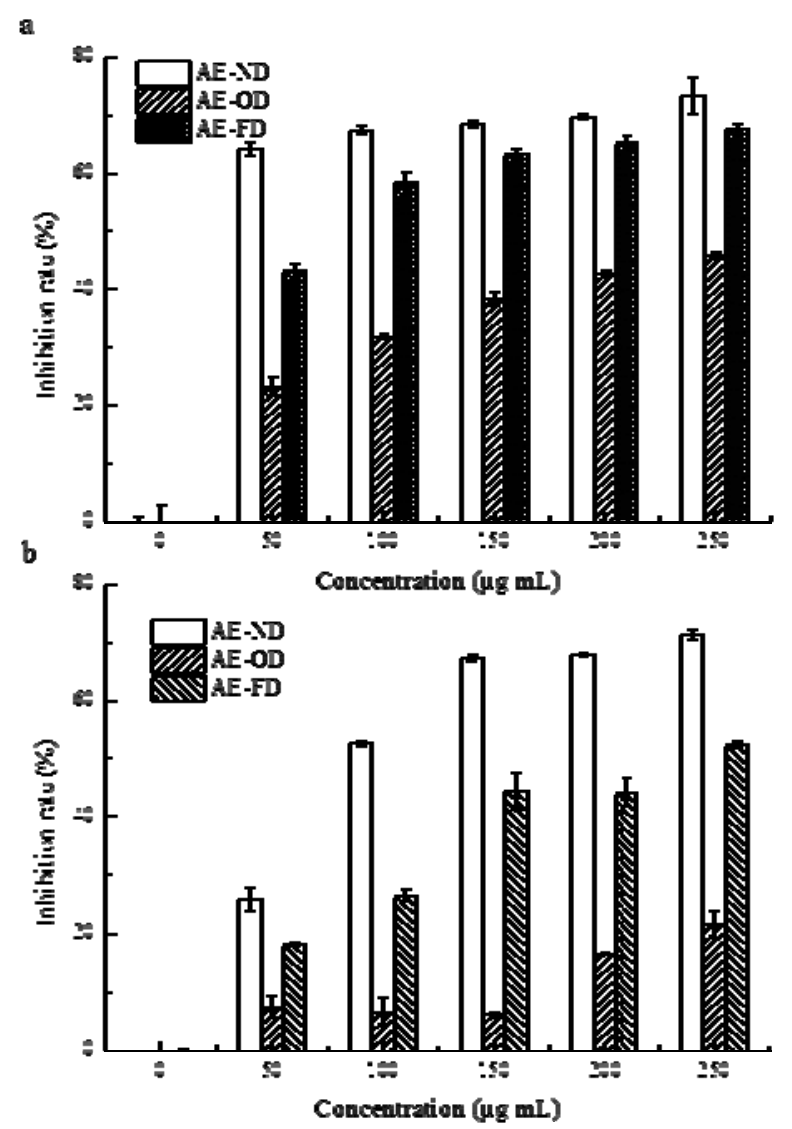

Figure 5. Anti-proliferation of aqueous extracts from SCR fermented by G. frondosa on HeLa cells. a: cells were incubated with various concentrations $(0,50,100,150,200,250 \mu \mathrm{g} / \mathrm{ml})$ of AE-ND, AE-OD and AE-FD for $24 \mathrm{~h} . \mathrm{b}$ : cells were incubated with various concentrations $(0,50,100,150,200,250 \mu \mathrm{g} / \mathrm{ml})$ of AE-ND, AE-OD and AE-FD for $48 \mathrm{~h}$. Data are expressed as means \pm S.D. $(n=3)(\mathrm{p}<0.05$ in comparison with control)

\section{Conclusions}

The results of the present work indicated that three aqueous extracts obtained from soybean curd residue fermented by $G$. frondosa showed different levels of strong antioxidant activities and also differently exhibited the immunomodulatory activities The results showed that three extracts exhibited antioxidant activities in a concentration-dependent manner. Among three extracts, AE-ON had a higher scavenging effects on DPPH free radical, $\mathrm{ABTS}^{+}$free radical and had potential reducing power. AE-FD had a higher capacity on the proliferation of RAW 264.7 cells and the apoptosis of HeLa cells. These results suggested proper drying methods should be supposed to adjust to various bio-activities. Hence, further research is concentrated on isolation, purification and function effects of SCR using various drying methods.

\section{References}

Ali, M., Cone, J. W., Hendriks, W. H., \& Struik, P. C. (2014). Oven-drying reduces ruminal starch degradation in maize kernels. Animal Feed Science and Technology, 193, 44-50. http://dx.doi.org/10.1016/j.anifeedsci. 2014.04.013

Bae, I. Y., Kim, H. Y., Lee, S. Y., \& Lee, H. G. (2011). Effect of the degree of oxidation on the physicochemical and biological properties of Grifola frondosa polysaccharides. Carbohydrate Polymers, 83(3), 1298-1302. http://dx.doi.org/10.1016/j.carbpol.2010.09.037

Borchani, C., Besbes, S., Masmoudi, M., Blecker, C., Paquot, M., \& Attia, H. (2011). Effect of drying methods on physico-chemical and antioxidant properties of date fibre concentrates. Food Chemistry, 125(4), 1194-1201. http://dx.doi.org/10.1016/j.foodchem.2010.10.030 
Brand-Williams, W., Cuvelier, M. E., \& Berset, C. (1995). Use of a free radical method to evaluate antioxidant activity. LWT - Food Science and Technology, 28(1), 25-30. http://dx.doi.org/10.1016/S0023-6438(95) 80008-5

C Ratti. (2001). Hot air and freeze-drying of high-value foods: a review. Journal of Food Engineering, 49(4), 311-319. http://dx.doi.org/10.1016/S0260-8774(00)00228-4

Chen, G. T., Ma, X. M., Liu, S. T., Liao, Y. L., \& Zhao, G. Q. (2012). Isolation, purification and antioxidant activities of polysaccharides from Grifola frondosa. Carbohydrate Polymers, 89(1), 61-66. http://dx.doi.org/10.1016/j.carbpol.2012.02.045

Chen, L., Zhang, X., Chen, J., Zhang, X. Z., Fan, H. H., Li, S. C., \& Xie, P. (2014). NF-кB plays a key role in microcystin-RR-induced HeLa cell proliferation and apoptosis. Toxicon, 87(1), 120-130. http://dx.doi.org/10.1016/j.toxicon.2014.06.002

Choi, E. Y., Kim, H. J., \& Han, J. S. (2014). Anti-inflammatory effects of calcium citrate in RAW 264.7 cells via suppression of NF-kB activation. Environmental Toxicology and Pharmacology, In Press, Accepted Manuscript. http://dx.doi.org/10.1016/j.etap.2014.11.002

Cui, F. J., Zan, X. Y., Li, Y. H., Yang, Y., Sun, W. J., Zhou, Q., Yu, S. L., \& Dong, Y. (2013). Purification and partial characterization of a novel anti-tumor glycoprotein from cultured mycelia of Grifola frondosa. International Journal of Biological Macromolecules, 62, 684-690. http://dx.doi.org/10.1016/j.ijbiomac.2013. 10.025

Debnath, T., Park, P. J., Nath, N. C. D., Samad, N. B., Park, H. W., \& Lim, B. O. (2011). Antioxidant activity of Gardenia jasminoides Ellis fruit extracts. Food Chemistry, 128(3), 697-703. http://dx.doi.org/10.1016/ j.foodchem.2011.03.090

Doymaz, İ. (2005). Drying behaviour of green beans. Journal of Food Engineering, 69(2), 161-165. http://dx.doi.org/10.1016/j.jfoodeng.2004.08.009

Fan, L. P, Li, J. W., Deng, K.Q., \& Ai, L. Z. (2012). Effects of drying methods on the antioxidant activities of polysaccharides extracted from Ganoderma lucidum. Carbohydrate Polymers, 87(2), 1849-1854. http://dx.doi.org/10.1016/j.carbpol.2011.10.018

Fan, Y. N., Wu, X. Y., Zhang, M., Zhao, T., Zhou, Y., Han. L., \& Yang, L. Q. (2011). Physical characteristics and antioxidant effect of polysaccharides extracted by boiling water and enzymolysis from Grifola frondosa. International Journal of Biological Macromolecules, 48(5), 798-803. http://dx.doi.org/10.1016/j.ijbiomac. 2011.03.013

Feng, S. S., \& Chien, S. (2003). Chemotherapeutic engineering: application and further development of chemical engineering principles for chemotherapy of cancer and other diseases. Chemical Engineering Science, 58(8), 4087-4114. http://dx.doi.org/10.1016/S0009-2509(03)00234-3

Floegel, A., Kim, D. O., Chung, S. J., Koo, S. I., \& Chun, O. K. (2011). Comparison of ABTS/DPPH assays to measure antioxidant capacity in popular antioxidant-rich US foods. Journal of Food Composition and Analysis, 24(7), 1043-1048. http://dx.doi.org/10.1016/j.jfca.2011.01.008

Garau, M. C., Simal, S., Rosselló, C., \& Femenia, A. (2007). Effect of air-drying temperature on physico-chemical properties of dietary fibre and antioxidant capacity of orange (Citrus aurantium v. Canoneta) by-product. Food Chemistry, 104(3), 1014-1024. http://dx.doi.org/10.1016/j.foodchem.2007.01.009

Gu, C. Q., Li, J. W., \& Chao, F. H. (2006). Inhibition of hepatitis B virus by D-fraction from Grifola frondosa: Synergistic effect of combination with interferon- $\alpha$ in HepG2 2.2.15. Antiviral Research, 72(2), 162-165. http://dx.doi.org/10.1016/j.antiviral.2006.05.011

Heras, R. M. L., Heredia, A., Castelló, M. L., \& Andrés, A. (2014). Influence of drying method and extraction variables on the antioxidant properties of persimmon leaves. Food Bioscience, 6, 1-8. http://dx.doi.org/10.1016/j.fbio.2014.01.002

Hilmi, F., Gertsch, J., Bremner, P., Valovic, S., Heinrich, M., Sticher, O., \& Heilmann, J. (2003). Cytotoxic versus anti-inflammatory effects in HeLa, jurkat $\mathrm{t}$ and human peripheral blood cells caused by guaianolide-Type sesquiterpene lactones. Bioorganic \& Medicinal Chemistry, 11(17), 3659-3663. http://dx.doi.org/10.1016/S0968-0896(03)00346-8 
Hsieh, C., Liu, C. J., Tseng, M. H., Lo, C. T., \& Yang, Y. C. (2006). Effect of olive oil on the production of mycelial biomass and polysaccharides of Grifola frondosaunder high oxygen concentration aeration. Enzyme and Microbial Technology, 39(3), 434-439. http://dx.doi.org/10.1016/j.enzmictec.2005.11.033

Kim, H. Y., Hwang, K. W., \& Park, S. Y. (2014). Extracts of Actinidia arguta stems inhibited LPS-induced inflammatory responses through nuclear factor- $\mathrm{\kappa B}$ pathway in Raw 264.7 cells. Nutrition Research, 34(11), 1008-1016. http://dx.doi.org/10.1016/j.nutres.2014.08.019

Kooli, S., Fadhel, A., Farhat, A., \& Belghith, A. (2007). Drying of red pepper in open sun and greenhouse conditions.: Mathematical modeling and experimental validation. Journal of Food Engineering, 79(3), 1094-1103. http://dx.doi.org/10.1016/j.jfoodeng.2006.03.025

Kurushima, H., Kodama, N., \& Nanba, H. (2000). Activities of polysaccharides obtained from Grifola frondosa on insulin-dependent diabetes mellitus induced by streptozotocin in mice. Mycoscience, 41(5), 473-480. http://dx.doi.org/10.1007/BF02461667

Kwon, D. J., Ju, S. M., Youn G. S., Choi, S. Y., \& Park, J. (2013). Suppression of iNOS and COX-2 expression by flavokawain A via blockade of NF-kB and AP-1 activation in RAW 264.7 macrophages. Food and Chemical Toxicology, 58, 479-486. http://dx.doi.org/10.1016/j.fct.2013. 05.031

Kwon, H. J., Bae, S. Y., Kim, K. H., Han, C. H., Cho, S. H., Nam. S. W., Choi, Y. H., \& Kim, B. W. (2007). Induction of apoptosis in HeLa cells by ethanolic extract of Corallina pilulifera. Food Chemistry, 104(1), 196-201. http://dx.doi.org/10.1016/j.foodchem.2006.11.031

Larrosa, A. P. Q., Jr., T. R. S. C., \& Pinto, L. A. A. (2015). Influence of drying methods on the characteristics of a vegetable paste formulated by linear programming maximizing antioxidant activity. LWT - Food Science and Technology, 60(1), 178-185. http://dx.doi.org/10.1016/j.lwt.2014.08.003

Lee, B. C., Bae, J. T., Pyo, H. B., Choe, T. B., Kim, S. W., Hwang, H. J., \& Yun, J. W. (2003). Biological activities of the polysaccharides produced from submerged culture of the edible Basidiomycete Grifola frondosa. Enzyme and Microbial Technology, 32(5), 574-581. http://dx.doi.org/10.1016/S0141-0229(03)00026-7

Lee, H. S., Ryu, D. S., Lee, G. S., \& Lee, D. S. (2012). Anti-inflammatory effects of dichloromethane fraction from Orostachys japonicus in RAW 264.7 cells: Suppression of NF-kB activation and MAPK signaling. Journal of Ethnopharmacology, 140(2), 271-276. http://dx.doi.org/10.1016/j.je2012.01.016

Li, S. H., Sang Y. S., Zhu, D., Yang, Y. N., Lei, Z. F., \& Zhang, Z. Y. (2013). Optimization of fermentation conditions for crude polysaccharides by Morchella esculenta using soybean curd residue. Industrial Crops and Products, 50, 666-672. http://dx.doi.org/10.1016/j.indcrop.2013.07.034

Li, S. H., Wang, L. B., Song, C. F., Hu, X. S., Sun, H. Y., Yang, Y. N., Lei, Z. F., \& Zhang, Z. Y. (2014). Utilization of soybean curd residue for polysaccharides by Wolfiporia extensa (Peck) Ginns and the antioxidant activities in vitro. Journal of the Taiwan Institute of Chemical Engineers, 45(1), 6-11. http://dx.doi.org/10.1016/j.jtice.2013.05.019

Li, X. B., Feng, T., Zhou, F., Zhou, S., Liu, Y. F., Li, W., Ye, R., \& Yang, Y. (2014). Effects of drying methods on the tasty compounds of Pleurotus eryngii. Food Chemistry, 166, 358-364. http://dx.doi.org/10.1016/j.foodchem.2014.06.049

Lue, B. m., Nielsen, N. S., Jacobsen, C., Hellgren, L., Guo, Z., \& Xu, X. B. (2010). Antioxidant properties of modified rutin esters by DPPH, reducing power, iron chelation and human low density lipoprotein assays. Food Chemistry, 123(2), 221-230. http://dx.doi.org/10.1016/j.foodchem.2010.04.009

Mau, J. L., Chang, C. N., Huang, S. J., \& Chen, C. C. (2004). Antioxidant properties of methanolic extracts from Grifola frondosa, Morchella esculenta and Termitomyces albuminosus mycelia. Food Chemistry, 87(1), 111-118. http://dx.doi.org/10.1016/j.foodchem.2003.10.026

Mohanty, C., Sahoo, K. S. (2010). The in vitro stability and in vivo pharmacokinetics of curcumin prepared as an aqueous nanoparticulate formulation. Biomaterials, 31(25), 6597-6611. http://dx.doi.org/10.1016/j.biomaterials. 2010.04 .062

Nakajima, Y., Sato, Y., \& Konishi, T. (2007). Antioxidant small phenolic ingredients in Inonotus obliquus (persoon) Pilat (Chaga). Chemical and Pharmaceutical Bulletin, 55(8), 1222-1226. http://dx.doi.org/10.1248/cpb.55.1222

Nanba, H., Kodama, N., Schar, D., \& Turner, D. (2000). Effects of Maitake (Grifola frondosa) glucan in HIV-infected patients. Mycoscience, 41(4), 293-295. http://dx.doi.org/10.1007/BF024 63941 
Oh, Y. C., Cho, W. K., Im G. Y., Jeong, Y. H., Hwang, Y. H., Liang, C., \& Ma, J. Y. (2012). Anti-inflammatory effect of Lycium Fruit water extract in lipopolysaccharide-stimulated RAW 264.7 macrophage cells. International Immunopharmacology, 13(2), 181-189. http://dx.doi.org/10.1016/j.intimp.2012.03.020

Parthiban, P., Pallela, R., Kim, S. K., Park, D. H., \& Jeong, Y. T. (2011). Synthesis of polyfunctionalized piperidone oxime ethers and their cytotoxicity on HeLa cells. Bioorganic \& Medicinal Chemistry Letters, 21(22), 6678-6686. http://dx.doi.org/10.1016/j.bmcl.2011.09.063

Sascha, C. T., Nicklisch, J., \& Herbert W. (2014). Optimized DPPH assay in a detergent-based buffer system for measuring antioxidant activity of proteins. MethodsX, 1, 233-238. http://dx.doi.org/10.1016/j.mex.2014. 10.004

Scala, K. D., \& Crapiste, G. (2008). Drying kinetics and quality changes during drying of red pepper. LWT Food Science and Technology, 41(5), 789-795. http://dx.doi.org/10.1016/j.lwt.2007.06.007

Shi, M., Zhang, Z. Y., \& Yang, Y. N. (2013). Antioxidant and immunoregulatory activity of Ganoderma lucidum polysaccharide (GLP). Carbohydrate Polymers, 95(1), 200-206. http://dx.doi.org/10.1016/j.carbpol. 2013.02.081

Sun, H. Y., Wang, S. F., Li, S. H., Yuan, X., Ma, J., \& Zhang Z. Y. (2013). Antioxidant Activity and Immunomodulatory of Extracts From Roots of Actinidia kolomikta. International Journal of Biology, 5(3), 1-12. http://dx.doi.org/10.5539/ijb.v5n3p1

Suvarnakuta, P., Chaweerungrat, C., \& Devahastin S. (2011). Effects of drying methods on assay and antioxidant activity of xanthones in mangosteen rind. Food Chemistry, 125(1), 240-247. http://dx.doi.org/10.1016/j.foodchem.2010.09.015

Tang, H. Y., Santamaria, A. D., Bachman, J., \& Park, J. W. (2013). Vacuum-assisted drying of polymer electrolyte membrane fuel cell. Applied Energy, 107, 264-270. http://dx.doi.org/10.1016/j.apenergy.2013.01.053

Van der Riet, W. B., Wight, A. W., Cilliers, J. J. L., \& Datel, J. M. (1989). Food chemical investigation of tofu and its byproduct okara. Food Chemistry, 34(3), 193-202. http://dx.doi.org/10.1016/03088146(89)90140-4

Xu, H., Liu, J. H., Shen, Z. Y., Fei, Y., \& Chen, X. D. (2010). Analysis of chemical composition, structure of Grifola frondosa polysaccharides and its effect on skin TNF- $\alpha$ levels, $\operatorname{lgG}$ content, T lymphocytes rate and caspase-3 mRNA. Carbohydrate Polymers, 82(3), 687-691. http://dx.doi.org/10.1016/j.carbpol. 2010.05.035

Yang, B., Wang, J., Zhao, M., Liu, Y., Wang, W., \& Jiang, Y. (2006). Identification of polysaccharides from pericarp tissues of litchi (Litchi chinensis Sonn.) fruit in relation to their antioxidant activities. Carbohydrate Research, 341(5), 634-638. http://dx.doi.org/10.1016/j.carres.2006.01.004

Yang, H. L., Zhang, L., Xiao, G. N., Feng, J. B., Zhou, H. B., \& Huang, F. R. (2014). Changes in some nutritional components of soymilk during fermentation by the culinary and medicinal mushroom Grifola frondosa. LWT - Food Science and Technology, In Press, Corrected Proof. http://dx.doi.org/10.1016/j.lwt.2014.05.027

Yuan, X., Hu, X. S., Liu, Y., Sun, H. Y., Zhang Z. Y., \& Cheng, D. L. (2014). In vitro and In vivo Anti-Diabetic Activity of Extracts From Actinidia kolomikta. International Journal of Biology, 6(3), 1-10. http://dx.doi.org/10.5539/ijb.v6n3p1

Zielinska, M., Zapotoczny, P., Alves-Filho, O., Eikevik, T. M., \& Blaszczak, W. (2013). A multi-stage combined heat pump and microwave vacuum drying of green peas. Journal of Food Engineering, 115(3), 347-356. http://dx.doi.org/10.1016/j.jfoodeng.2012.10.047

\section{Copyrights}

Copyright for this article is retained by the author(s), with first publication rights granted to the journal.

This is an open-access article distributed under the terms and conditions of the Creative Commons Attribution license (http://creativecommons.org/licenses/by/3.0/). 